\title{
Gastroenteroviruses Infection in Taiwan
}

\author{
Tsong-Ming $\mathrm{Lu}^{1,2}$, Hsiu-Ting Tsai ${ }^{3}, \mathrm{Yu}-$ Wen Cheng ${ }^{4}$, Lengsu William Chin ${ }^{1,5}$ and \\ Chi-Chiang Yang ${ }^{*}, 6$
}

\author{
${ }^{1}$ Institute of Medicine, Chung Shan Medical University, Taichung, Taiwan, Republic of China \\ ${ }^{2}$ Department of Neurology, Chung Shan Medical University Hospital, Taichung, Taiwan, Republic of China \\ ${ }^{3}$ School of Nursing, Chung Shan Medical University, Taichung, Taiwan, Republic of China \\ ${ }^{4}$ Department of Internal Medicine, Lee General Hospital, Miaoli, Taiwan, Republic of China \\ ${ }^{5}$ Emergency Department, Da Chien General Hospital, Miaoli, Taiwan, Republic of China \\ ${ }^{6}$ School of Medical Laboratory and Biotechnology, Chung Shan Medical University, Taichung, Taiwan, Republic of \\ China
}

\begin{abstract}
Acute infectious gastroenteritis causes high morbidity and mortality in children worldwide. The most important cause of gastroenteritis is virus infection. Diarrhea is the dominant symptom of viral gastroenteritis. It subsequently induces dehydration and malnutrition, which contribute to high morbidity and mortality in children. In Taiwan, rotavirus is the major cause $(30.4-48 \%)$ of infectious gastroenteritis, followed by adenovirus $(9.1-19.8 \%)$, norovirus $(8.2-25 \%)$, enterovirus $(<5.2 \%)$, astrovirus $(2.7-2.9 \%)$ and other viruses (including sapovirus) $(<1 \%)$. Untreated gastroenteritis is the major cause of infantile mortality, which leads to human tragedy and economic burden. In Taiwan, the cost of admission or hospitalization associated with gastroenterovirus infection is about more than $40 \%$ of the monthly salary of an unskilled or service worker. Understanding the epidemiology of gastroenterovirus and its induced host immune response could benefit the development for prevention and therapeutic management of gastroenterovirus. This review summarizes the epidemiological information and current knowledge of gastroenteroviruses that cause gastroenteritis in Taiwan.
\end{abstract}

Keywords: Gastroenterovirus, Gastroenteritis, Taiwan.

\section{INTRODUCTION}

Acute infectious gastroenteritis causes high morbidity and mortality in children worldwide. This disease is characterized by watery diarrhea, dysentery, or/and accompanied by bloody diarrhea, chronic diarrhea, fever, dehydration, vomiting, nausea, abdominal pain, and extraintestinal manifestations, or asymptomatic infections. Untreated gastroenteritis is the major cause of infantile mortality, which leads to human tragedy and economic burden. In Taiwan, the cost of admission or hospitalization associated with gastroenterovirus infection is about more than $40 \%$ of the monthly salary of an unskilled or service worker [1]. Among the causes of gastroenteritis, viral infection which accounts for 51.2$88.3 \%$ incidence is the most important, whereas exclusively bacterial infection $(9.1-13.4 \%)$ or concomitant bacterial and viral infection (2.6-7.3\%) appeared to be responsible for smaller proportions [2-4]. Understanding the incidence rate and epidemiological diversities of gastroenteroviruses, which contribute to most gastroenteritis in Taiwanese, is one of the important strategies for preventing gastroenteroviruses infection. To provide an effective direction for preventing infections in Taiwan, this review summarizes the epidemiological

*Address correspondence to this author at the School of Medical Laboratory and Biotechnology, Chung Shan Medical University, 110, Section 1, ChienKuo North Road, Taichung, Taiwan 402, Republic of China; Tel: 886-424730022; Ext: 11716; Fax: 886-4-23767469; E-mail: cyang@csmu.edu.tw information and current knowledge of gastroenteroviruses that cause gastroenteritis in Taiwan. We describe herein the classification and structure, epidemiological diversity, clinical manifestations and pathogenesis of respective gastroenteroviruses including rotavirus, adenovirus, calicivirus (norovirus and sapovirus), astrovirus and enterovirus. Their basic characteristics were listed in Table 1. Moreover, the host immune responses to gastroenterovirus infections are also discussed.

\section{ROTAVIRUS}

Rotavirus is a member of the Reoviridae family. Its genome consists of eleven double-stranded RNA gene segments, which encode five structural and six non-structural proteins. The virus particles are composed of double-layered protein capsids with a diameter of $60-80 \mathrm{~nm}$. The core of the virus particle comprises VP1, VP2 and VP3 [5]. The antigenic specificity of the inner capsid protein VP6 is classified into seven distinct groups, A, B, C, D, E, F and G. However, only groups $\mathrm{A}, \mathrm{B}$ and $\mathrm{C}$ have been identified in humans, and the most common group leading to outbreaks is group A rotavirus [6-8]. Despite much effort made, we are unable to identify any group B or group C rotavirus in Taiwan [9]. Two outer capsid proteins, VP7 and VP4, are involved in induction of neutralizing antibodies after infected with rotavirus, and are employed to define the virus $\mathrm{G}$ and $\mathrm{P}$ serotypes, respectively $[6,7,10]$. Nowadays, at least $14 \mathrm{G}$ and 20 
Table 1. The Basic Characteristics of Gastroenteroviruses Discussed in this Review

\begin{tabular}{|c|c|c|c|c|}
\hline Virus & Genome & Capsid & Envelope & Virion Diameter (nm) \\
\hline \hline Rotavirus & Segmented double-stranded RNA & Icosahedron (Double capsids) & No & $60-80$ \\
\hline Adenovirus & Linear double-stranded DNA & Icosahedron & No & $70-90$ \\
\hline Calicivirus (Norovirus and Sapovirus) & Linear positive single-stranded RNA & Icosahedron & No & $35-40$ \\
\hline Astrovirus & Linear positive single-stranded RNA & Icosahedron & No & $28-30$ \\
\hline Enterovirus & Linear positive single-stranded RNA & Icosahedron & No & $22-30$ \\
\hline
\end{tabular}

P serotypes out of $15 \mathrm{G}$ and $28 \mathrm{P}$ genotypes have been identified in humans [10].

The predominant viral pathogen of gastroenteritis in the world is rotavirus $[3,11]$. The majority of rotavirus infection is asymptomatic or causes gastroenteritis episodes, which are self-limited and last for several days [12-14]. The clinical manifestations of rotavirus gastroenteritis include diarrhea (92-99\%), fever $(55-79 \%)$, dehydration $(78-88 \%)$, vomiting (45-73\%), bloody stool (3-8\%), and seizure (3-5\%) [4, 12, 15, 16]. More than $90 \%$ of children infected with rotavirus are younger than three years old [17]. It is also the first leading cause $(30.4-48 \%)$ of virus infectious gastroenteritis, which also accounts for $92 \%$ of nosocomial infectious gastroenteritis, among children in Taiwan [2-4, 15, 18-22]. It occurs year round $[15,18,19]$ in Taiwan, with more than $48 \%$ of gastroenteritis among children under five years old occurring in summer [2, $18,22]$ and even more frequent, around $76-83 \%$, in winter $[4$, $15,18,21]$.

Clinical manifestations of G1 and G9 rotavirus infection include diarrhea, fever, dehydration, and vomiting $[4,15]$. However, seizure attack is likely to present in rotavirus gastroenteritis patients with G1 or G2 serotype in northern Taiwan [15] and G9 serotype in southern Taiwan [4]. The common $\mathrm{G}$ serotypes of rotavirus gastroenteritis identified in southern Taiwan are G1 (20-51\%) and G9 (21-31\%), followed by G3 (12-27\%), G2 (3-16\%), and G4 (1-3\%) [4, 17]. However, it was also reported that G9 (37\%) is the most common serotype identified in Taiwan between 2001 and 2003 , followed by G1 (31\%), G2 (10\%), G3 (9.3\%), and G4 serotypes (3.7\%) [19]. Since 1992, serotype G9 strains have been detected in several countries [23], such as Italy [24], Libya [25], Kenya [25], Cuba [25], Japan [26], Thailand [26], Brazil [27], Argentina [28], France [29], England [30], Australia [31], America [32], Bangladesh [33], and India [34]. This indicates the gradual increase in frequency of serotype G9 infection, which may become one of the most important serotypes causing virus gastroenteritis [35]. Our previous investigation has found high prevalence of G9 strains in Taiwan, and suggested the shift of rotavirus genotype from type G1 before 1996, to G9 in 2001 and 2002, as well as the re-emergence of G3 type in 2002 [9]. Specifically, one strain named CS02-04 belonged to serotype G9, it possessed a high concordance in nucleotide and deduced amino acid sequence of VP7 to SP2737, which was from Japan. Comparing the difference in amino acid among the rotavirus strains in our previous study [9] and their most closely related reference strains reveals that VR3, rather than VR5, VR7 or VR8, was the most frequently mutated region of VP7 [9]. G1, G3, and some of the G9 strains all showed one or two amino acid substitutions in the $\mathrm{H} 2$ hydrophobic region. Moreover, Lin et al. [36] and Chen et al. [19] also found that G9 rotaviruses emerged between 2000 and 2002 in northern Taiwan, as well as between 2001 and 2003 all over Taiwan. In their studies, most of the G9 strains belonged to G9 P[8] $[19,36]$, subgroup II, and long electrophorotype, and only one strain belonged to G9 P[4], subgroup II, and short electrophorotype [36]. Nevertheless, it has been reported that G2 strains were detected from 1981 to 1987, and then became undetected for several years until 1992. Subsequently, reassortant G2 viruses caused an outbreak of gastroenteritis in northern Taiwan in 1993 [21]. Later, G2 rotavirus strains [21] were found to resemble genetically to an atypical serotype G2 rotavirus strain isolated in Australia [37]. It was also proposed that E210 (serotype G2P1B), which caused an outbreak of gastroenteritis in central and northern Australia in 1993-1994 [38], was derived from the reassortment event between Taiwanese G2 strains imported into Australia and a local non-G2 virus [37]. These results from Taiwan support the view that a worldwide G9 prevalence is in progress. The observations concerning high circulation of G9 strains have strong implications for the clinical application of a suitable rotavirus vaccine, for example Rotarix, for use in Taiwan, because the available vaccine, Rotateq, which targets only G1-G4, does not offer adequate protection from such a serotype.

\section{ADENOVIRUS}

Adenoviruses are viral particles measuring $70 \mathrm{~nm}$ to 90 $\mathrm{nm}$ in diameter with double-stranded DNA. More than 49 immunologically distinct types of adenovirus have been found from humans. The most common manifestations of adenovirus infection involve both respiratory and gastrointestinal tracts. Adenovirus types 40 and 41 (Ad40 and Ad41), which result in gastroenteritis only with few respiratory symptoms, are referred as enteric adenoviruses.

Enteric adenovirus-associated gastroenteritis is usually mild and self-limited. For acute infection of entericadenovirus infection, severe diarrhea $(92-97 \%)$ is the predominant symptom, with a mean duration of 8.6 days (Ad40) and 12.2 days (Ad41), respectively [12]. Prolongation of symptoms more than or equal to 14 days and low frequency of respiratory symptoms, around $21 \%$, also exhibit for onethird of the children diagnosed with Ad41 infection [12,39]. Besides diarrhea, fever (55-69\%), vomiting (45-50\%), dehydration (44-78\%), bloody stool (3-6\%), abdominal pain $(12.5 \%)$, symptoms of upper respiratory tract infection $(21.9 \%)$, and seizure $(3 \%)$ are also found in patients with adenovirus infection $[4,12]$. Among all patients with diarrhea, $72.2 \%$ have watery diarrhea in, $20 \%$ have diarrhea with 
mucus, $3.1 \%$ have diarrhea with blood, and $1.6 \%$ have diarrhea with both mucus and blood [12].

In Taiwan, adenovirus is an important pathogen causing severe gastroenterovirus in children younger than two years old [12]. It may be the second leading cause of acute infantile virus gastroenteritis worldwide [39-41], as well as in Taiwan $[2,18,20]$. It accounts for around $9.1-19.8 \%$ of virus infectious gastroenteritis in Taiwan [2, 18]. Although it is reported that infection with type 40 or type 41 adenovirus was usually endemic with no seasonal variation [39], the incidence rate of enteric adenovirus in southern Taiwan peaked from October to December and declined rapidly in early spring [18].

\section{CALICIVIRUS}

The Caliciviridae family is a family of viruses with a non-segmented positive-sense RNA. The caliciviruses have a simple construction and are not enveloped. The capsid appears hexagonal/spherical and has icosahedral symmetry with a diameter of 35-40 nm. Norovirus (previously called "Norwalk-like viruses") together with the sapoviruses are caliciviruses causing acute viral gastroenteritis in humans.

Noroviruses often cause explosive outbreaks of acute gastroenteritis in institutions. Norovirus infection is generally mild and self-limited [42]. The clinical symptoms include diarrhea, vomiting, fever, and stool occult blood [3]. Noroviruses can be genetically classified into five different genogroups (GI, GII, GIII, GIV and GV), which can be further divided into different genetic clusters or genotypes. Genogroups I, II and IV infect humans [43]. The most prevalent human genogroup, genogroup II,-contains 19 genotypes [44]. Noroviruses from genogroup II, genotype 4 (abbreviated as GII/4) account for the majority of adult outbreaks of gastroenteritis and often sweep across the globe. For example, the US95/96-US strain was associated with global outbreaks in the mid- to late-90s. In 2006, there was another large increase in norovirus infection around the globe [45]. In 2007, there was an outbreak in northern California where around 80-100 people were infected.

Noroviruses are highly contagious, with an inoculum of as few as 10-100 particles being able to cause infection [46]. Transmission occurs through ingesting contaminated food and water and infection spreads by person-to-person. Transmission is predominantly faecal-oral but may be airborne due to aerosolization of vomit. It is an etiological agent for viral acute gastroenteritis in humans of all ages [42] and accounts for $8.2-25 \%$ of viral gastroenteritis in Taiwan $[3,18]$. Contamination of foods or drinking water by norovirus is one of the leading causes of gastroenteritis outbreaks. However, it has been found that the top incidences of norovirus and rotavirus occurred during cold weather with and relatively low precipitation, but its occurrence was not associated with relative humidity [3]. Norovirus seems to occur more commonly between winter and early spring in southern Taiwan [18]. It was reported that the incidence rate can reach as high as $31.8 \%$ between December and February in northern Taiwan [3]. The sub-genotype GII/4 (83\%) is the dominant genotype of norovirus, and it is one of the majority genotypes that contribute to outbreaks of gastroenteritis in Taiwan between November 2004 and March 2005 [47]. In addition, during that period, different outbreaks of norovirus strains were attributed to different distinct genotypes. Moreover, norovirus GII strains Taipei-81K/Taipei-84K and Taipei-91L/TaipeiGII-93L were found in the same outbreaks. In addition, their sequences shared short conserved sites of 10 nucleotides at the 5' end of the capsid gene, suggesting that norovirus recombination events occurred when one strain came in contact with the other [47].

Sapoviruses have been reported to induce sporadic infection in both young children and adults. Four genogroups (GI, GII, GIII and GIV) of sapoviruses are classified, though only GI, GII and GIV are known to infect humans. In northern Taiwan, genogroup I/genotype II sapovirus-associated outbreak of gastroenteritis occurred in 55 college students in May, 2007 [48]. In general, the annul incidence of gastroenteritis induced by sapovirus in Taiwan was low and estimated to be below $1 \%$. Clinical manifestations, continued for around 10 days, include diarrhea, vomiting, abdominal cramps, and fever [48].

\section{ASTROVIRUS}

Astrovirus belongs to the Astroviridae family and is a small non-enveloped virion with a diameter of 28-30 nm. It contains a single-stranded positive-sense RNA of $6.8 \mathrm{~kb}$, and its characteristic five- or six-pointed star morphology has been detected by electron microscopy [49]. Astrovirus is hardy and relatively resistant to heat, ultraviolet irradiation, chlorine, and extreme changes in $\mathrm{pH}$ [50]. Watery diarrhea is the predominant manifestation and usually lasts for 2-6 days. Bloody stools, febrile, abdominal pain, vomiting, cough, rhinorrhea, skin rash, and hematochezia are also observed in patients with astrovirus infection, and the majority of patients recover without specific treatment [51].

Epidemiologic studies have revealed that astrovirus is one of the significant causes of gastroenteritis in children, with a prevalence rate of around $2.9 \%$, in Taiwan $[2,18,51]$. The nosocomial infection rate is approximately $16.7 \%$, and astrovirus gastroenteritis is most prevalent in northern Taiwan between autumn and winter, particularly in December [51].

\section{ENTEROVIRUS}

The Enterovirus genus includes distinct serotypes of viruses which belong to the family of Picornaviridae, such as three types of polioviruses, 24 types of coxsackie A viruses, six types of coxsackie B viruses, 34 types of echoviruses, and enterovirus types 68 to 71 [52]. Most of the enteroviruses are morphologically alike and have the characteristic of a small $(7.7 \mathrm{~kb})$ single strand RNA, and a diameter of 20 to $30 \mathrm{~nm}$.

The incidence rates of enterovirus infections vary widely. It has reported that around $5.2 \%$ of pediatric viral gastroenteritis in Taiwan is attributed to enterovirus infections [2]. The peak incidence rate for most of the enterovirus infections occurs from May to October [53], and most of those infected are younger than five years old [54]. The infections of enteroviruses are usually mild or asymptomatic, and vary with the specific enterovirus. Moreover, different serotypes of enterovirus infections may induce similar clinical manifestations, while the same serotype may have different manifestations. Paralysis is usually induced by poliovirus infection. However, infections of enterovirus types 68 to 71, par- 
ticularly for enterovirus 71 (EV71) infection, which are endemic in Taiwan for the past decade, can induce severe or fatal manifestations such as the lesions of hand, foot, and mouth syndrome-associated encephalitis, viral meningitis, acute flaccid paralysis, encephalomyelitis, cardiopulmonary failure, or central nervous system involvement rather than gastroenteritis [53-56].

\section{TRANSMISSIONS OF GASTROENTEROVIRUSES AND HOST IMMUNE RESPONSES}

Transmissions of gastroenteroviruses can be induced by food-borne transmission, person-to-person contact, contaminated drinking water, and environmental contaminations. Innate immunity functions in response to foreign pathogens. Toll-like receptors (TLRs) are transmembrane proteins expressed by cells of the innate immune system, which recognize invading microbes and activate signaling pathways that launch immune and inflammatory responses to destroy the invaders. For example, it was reported that TLR3 activates immune cells and mediators, including natural killer cells and interferon gamma, in response to double-stranded viral RNA, a molecular signature of most viruses [57]. In recent years, it has been suggested that the protein melanoma differentiation-associated gene-5 (MDA-5) may be the primary immune sensor, and to a lesser extent, TLR3, that detects the presence of noroviruses in the body [58]. People with common variations of the MDA-5 gene are more susceptible to norovirus infection. MDA-5 and TLR3 are both intracellular proteins responded by causing other cells to release interferon, which shuts down production of the virus and initiates a full-scale immune attack. During the initial stage, early innate responses may be triggered by the episode of infection in order to recognize and limit the spread of infection when adaptive immune response is developing.

Cellular and humoral immune responses are considered as the crucial defense for disease prevention as well as control and clearance of virus infection. It was found that B cells, monocytes, and dendritic cells are susceptible to the initial steps of gastroenterovirus infection [59,60]. Dendritic cells have been regarded as the main source of IFN$\alpha$ production [59] and the important activator for specific $\mathrm{T}$ cells $[59,60]$. Moreover, macrophage-activated cytotoxic $\mathrm{T}$ cells and helper $\mathrm{T}$ cells are associated with the persistence of memory $\mathrm{T}$ cells [61].

When infected with pathogens, microbial proteins are processed and found to promote the activation of $\mathrm{T}$ lymphocytes. It has been reported that the activated specific cytotoxic $\mathrm{T}$ lymphocytes destroy directly virus-infected cell by recognition of the virus antigen presented on the surface of major histocompatibility complex (MHC) class I, and inactivate intracellular viral proteins by secretion of cytokines $[62,63]$. Helper T cells are essential for the development of immunoglobulin, eosinophil activation, cytokine production, and contribute to the phagocyte-dependent and independent protective responses [64]. Moreover, individuals with T-cell immunodeficiency are susceptible to chronic enteric virus infections [65]. Development of T-helper type 1 (Th1) and T-helper type 2 (Th2) cells from their precursor cells is augmented through signal transduction initiated by the innate immune system [66-69] as well as the initiation and regula- tion in accordance with cytokine production during responses to infectious agents [67,69-71].

Although the specific mechanisms are not well understand, it was reported that cytotoxic $\mathrm{T}$ lymphocytes play an important role in viral clearance during primary gastroenterovirus infections, such as rotaviruses [72], noroviruses [73], and enteroviruses infections [74]. Virions devoured by antigen-presenting cells (APCs) and the released viral proteins can elicit activation of $\mathrm{T}$ cells [75]. It was reported that infected dendritic cells serve to act as the antigen-presenting cells for the recognition of virus antigen by cytotoxic $\mathrm{T}$ cells [61] and low concentrations of endogenous synthesis of viral antigen are necessary for priming of cytotoxic $\mathrm{T}$ cells [76]. VP7 protein of rotavirus is a principle target of specific cytotoxic T lymphocytes [77]. The response of cytotoxic $\mathrm{T}$ cells to rotavirus infection peaks on days 5 to 7 after infection and then declines rapidly in infected mice [78]. After exposure of human peripheral blood mononuclear cells to rotavirus, the rotaviruses non-structural proteins are expressed in T cells, B cells, natural killer cells, monocytes, and dendritic cells. However, these expressions are abolished by anti-VP7 neutralizing antibodies [59].

For $\operatorname{IgG}, \operatorname{IgG} 1$ and $\operatorname{IgG} 3[79,80]$ act as host defenses against astrovirus infection. However, we believe that this also holds true for other gastroenteroviruses, since our previous studies and other research groups have shown that IgG1 and IgG3 are the main IgG subclasses found in infection by human cytomegalovirus [81], human herpes virus 6 [82], hantavirus [83, 84], and human immunodeficiency virus [85], and hepatitis B virus [86-89]. The cross-regulation between Th1 and Th2 cytokines is associated with the development of antigen pathogenesis [64]. It was found that the recombinant GII/4 norovirus capsid protein can induce strong Th1-Th2-like cellular immune responses [73]. The mRNA expression of Type 1 T-helper cell cytokines, such as interferon gamma (IFN- $\gamma$ ), interleukin (IL)12, and Type 2 T-helper cell cytokine IL4, have been found after onset of diarrhea and then reduced on day 3, in peripheral blood mononuclear cells of gastroenteritis patients with rotavirus infection [14]. Moreover, it was found that tumor necrosis factor (TNF)- $\alpha$ and IFN- $\gamma$ secretion are significantly increased, and IL-2 cytokine levels were moderately increased after transfection of recombinant GII/4 norovirus capsid protein gene into BALB/c mice [73]. TNF- $\alpha$ has been suggested to be associated with the defense against adenovirus infection [90].

The secretory intestinal immunoglobulin A (IgA) is presented with rotaviruses [91], astroviruses [92], and astroviruses infection [93]. Th2 cytokines, IL-5, promoting IgA production, was consistently and significantly elevated with high serum and mucosal IgA antibody titers [73].

\section{CONCLUSION}

In Taiwan, similar to other countries, rotavirus is the major cause $(30.4-48 \%)$ of infectious gastroenteritis, followed by adenovirus (9.1-19.8\%), norovirus (8.2-25\%), enterovirus $(<5.2 \%)$, astrovirus $(2.7-2.9 \%)$ and other viruses (including sapovirus) $(<1 \%)$ (Fig. 1). Diarrhea is the dominant symptom of viral gastroenteritis. It subsequently induces dehydration and malnutrition, which contribute to high morbidity and mortality. Multiple viruses infection caused the highest 


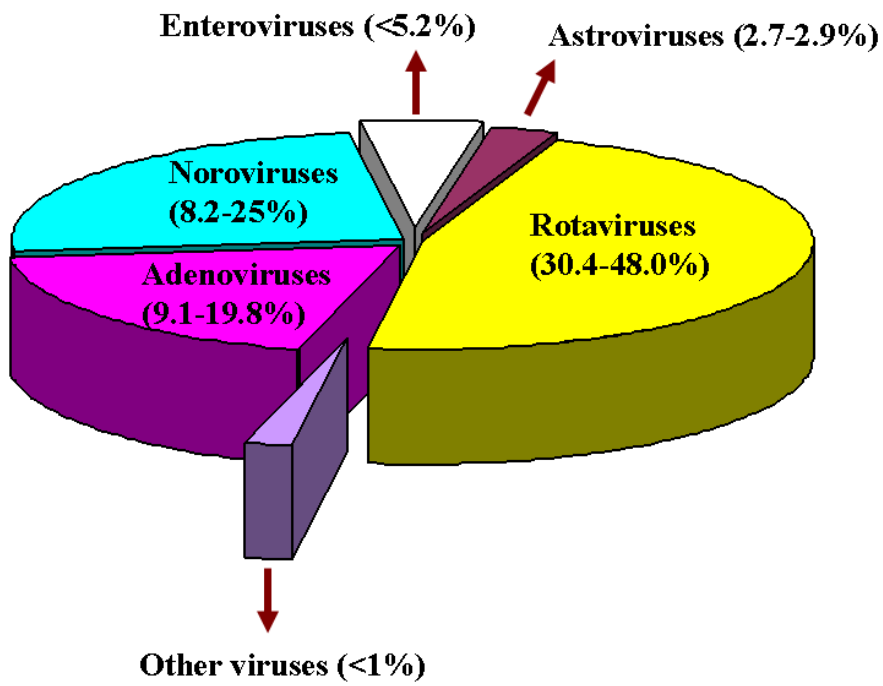

Fig. (1). Percentage of contribution of gastroenteroviruses to gastroenteritis in Taiwan.

total intestinal disorder severity score of viral gastroenteritis, followed by rotavirus infection [3, 4]. In Taiwan, gastroenterovirus infections usually occur all year round although a high prevalence rate is mainly found in winter season. Prevention against viral gastroenteritis throughout the year is necessary, particularly for children younger than five years old. Sanitary living conditions, efficient sewage treatment, intake of hygienic food and water, and avoidance of personto-person infection are important strategies for preventing viral gastroenteritis. Finally, understanding the epidemiology of gastroenterovirus and its induced host immune response could benefit the development for prevention and therapeutic management of gastroenterovirus.

\section{ABBREVIATIONS}

$$
\begin{array}{ll}
\text { APCs } & =\text { Antigen presenting cells } \\
\text { IFN- } \gamma & =\text { Interferon gamma } \\
\text { IgA } & =\text { Immunoglobulin A } \\
\text { IgG } & =\text { Immunoglobulin G } \\
\text { IL } & =\text { Interleukin } \\
\text { MDA-5 } & =\text { Melanoma differentiation-associated gene-5 } \\
\text { MHC } & =\text { Major histocompatibility complex } \\
\text { Th1 } & =\text { T-helper type } 1 \\
\text { Th2 } & =\text { T-helper type } 2 \\
\text { TLRs } & =\text { Toll-like receptors } \\
\text { TNF } & =\text { Tumor necrosis factor }
\end{array}
$$

\section{REFERENCES}

Chen KT, Fan SF, Tang RB, et al. Hospital-based study of the economic burden associated with rotavirus diarrhea in Taiwan. Vaccine 2007; 25(21): 4266-72.

[2] Yang CC, Ku CS, Lin SJ, Marguerite B, Chen CK. Diagnosis of gastroenteric viruses in fecal specimens from pediatric patients in Taiwan. J Biomed Lab Sci 2001; 13: 63-71.
[3] Chen SM, Ni YH, Chen HL, Chang MH. Microbial etiology of acute gastroenteritis in hospitalized children in Taiwan. J Formos Med Assoc 2006; 105(12): 964-70.

[4] Sung YL, Huang YF, Huang CF, et al. Emergence of G9 serotype rotavirus as a major cause of infectious gastroenteritis in southern Taiwan. J Microbiol Immunol Infect 2004; 37(6): 322-6.

[5] Lawton JA, Zeng CQ, Mukherjee SK, Cohen J, Estes MK, Prasad BV. Three-dimensional structural analysis of recombinant rotavirus-like particles with intact and amino-terminal-deleted VP2: implications for the architecture of the VP2 capsid layer. J Virol 1997; 71(10): 7353-60.

[6] Hoshino Y, Jones RW, Chanock RM, Kapikian AZ. Generation and characterization of six single VP4 gene substitution reassortant rotavirus vaccine candidates: each bears a single human rotavirus VP4 gene encoding $P$ serotype $1 \mathrm{~A}[8]$ or $1 \mathrm{~B}[4]$ and the remaining 10 genes of rhesus monkey rotavirus MMU18006 or bovine rotavirus UK. Vaccine 2002; 20(29-30): 3576-84.

[7] Kapikian AZ, Hoshino Y, Chanock RM, Perez-Schael I. Efficacy of a quadrivalent rhesus rotavirus-based human rotavirus vaccine aimed at preventing severe rotavirus diarrhea in infants and young children. J Infect Dis 1996; 174(Suppl 1): S65-72.

[8] Hoshino Y, Kapikian AZ. Rotavirus antigens. Curr Top Microbiol Immunol 1994; 185: 179-227.

[9] Lai HC, Lin SJ, Lin HR, Ku CS, Wang L, Yang CC. Phylogenetic analyses of human rotavirus in central Taiwan in 1996, 2001 and 2002. J Clin Virol 2005; 32(3): 199-217.

[10] Martella V, Ciarlet M, Bányai K, et al. Identification of a novel VP4 genotype carried by a serotype G5 porcine rotavirus strain. Virology 2006; 346(2): 301-11.

[11] Fruhwirth M, Karmaus W, Moll-Schuler I, Brosl S, Mutz I. A prospective evaluation of community acquired gastroenteritis in paediatric practices: impact and disease burden of rotavirus infection. Arch Dis Child 2001; 84(5): 393-7.

[12] Lin $\mathrm{HC}$, Kao CL, Lu CY, et al. Enteric adenovirus infection in children in Taipei. J Microbiol Immunol Infect 2000; 33(3): 17680 .

[13] Zheng BJ, Lo SK, Tam JS, Lo M, Yeung CY, Ng MH. Prospective study of community-acquired rotavirus infection. J Clin Microbiol 1989; 27(9): 2083-90.

[14] Lin AY, Lin CY, Chen CT, Chen WL. Host defense against Salmonella and rotaviral gastroenteritis: a serial study of transcriptional factors and cytokines. J Microbiol Immunol Infect 2008 ; 41(3): 265-71.

[15] Chiu TF, Lee CN, Lee PI, et al. Rotavirus gastroenteritis in children: 5-year experience in a medical center. J Microbiol Immunol Infect 2000; 33(3): 181-6. 
[16] Lin SC, Hsu HY, Wang PJ, et al. Rotavirus gastroenteritis associated with afebrile seizure in childhood. Zhonghua Min Guo Xiao Er Ke Yi Xue Hui Za Zhi 1996; 37(3): 204-7.

[17] Kapikian AZ, Hoshino Y, Chanock RM. Rotavirus. In: Knipe DM, Howley PM, Eds. Fields virology, $4^{\text {th }}$ ed. Philadelphia: LippincottRaven 2001; 2: pp. 1787-1833.

[18] Chen SY, Chang YC, Lee YS, et al. Molecular epidemiology and clinical manifestations of viral gastroenteritis in hospitalized pediatric patients in Northern Taiwan. J Clin Microbiol 2007; 45(6): 2054-7.

[19] Chen KT, Chen PY, Tang RB, et al. Sentinel hospital surveillance for rotavirus diarrhea in Taiwan, 2001-2003. J Infect Dis 2005; 192 (Suppl 1): S44-48.

[20] Liu LJ, Yang YJ, Kuo PH, Wang SM, Liu CC. Diagnostic value of bacterial stool cultures and viral antigen tests based on clinical manifestations of acute gastroenteritis in pediatric patients. Eur $\mathbf{J}$ Clin Microbiol Infect Dis 2005; 24(8): 559-61.

[21] Zao CL, Yu WN, Kao CL, Taniguchi K, Lee CY, Lee CN. Sequence analysis of VP1 and VP7 genes suggests occurrence of a reassortant of $\mathrm{G} 2$ rotavirus responsible for an epidemic of gastroenteritis. J Gen Virol 1999; 80 (Pt 6): 1407-15.

[22] Echeverria P, Ho MT, Blacklow NR, et al. Relative importance of viruses and bacteria in the etiology of pediatric diarrhea in Taiwan. J Infect Dis 1977; 136(3): 383-90.

[23] Aranda-Michel J, Giannella RA. Acute diarrhea: a practical review. Am J Med 1999; 106(6): 670-6.

[24] Arista S, Vizzi E, Migliore MC, Di Rosa E, Cascio A. High incidence of G9P181 rotavirus infections in Italian children during the winter season 1999-2000. Eur J Epidemiol 2003; 18(7): 711-4.

[25] Cunliffe NA, Dove W, Bunn JE, et al. Expanding global distribution of rotavirus serotype G9: detection in Libya, Kenya, and Cuba. Emerg Infect Dis 2001; 7(5): 890-2.

[26] Zhou Y, Supawadee J, Khamwan C, et al. Characterization of human rotavirus serotype G9 isolated in Japan and Thailand from 1995 to 1997 . J Med Virol 2001; 65(3): 619-28.

[27] Araujo IT, Ferreira MS, Fialho AM, et al. Rotavirus genotypes $\mathrm{P}[4] \mathrm{G} 9, \mathrm{P}[6] \mathrm{G} 9$, and $\mathrm{P}[8] \mathrm{G} 9$ in hospitalized children with acute gastroenteritis in Rio de Janeiro, Brazil. J Clin Microbiol 2001; 39(5): 1999-2001.

[28] Bok K, Palacios G, Sijvarger K, Matson D, Gomez J. Emergence of G9 P[6] human rotaviruses in Argentina: phylogenetic relationships among G9 strains. J Clin Microbiol 2001; 39(11): 4020-5.

[29] Bon F, Fromantin C, Aho S, Pothier P, Kohli E. G and P genotyping of rotavirus strains circulating in france over a three-year period: detection of $\mathrm{G} 9$ and $\mathrm{P}[6]$ strains at low frequencies. The AZAY Group. J Clin Microbiol 2000; 38(4): 1681-3.

[30] Iturriza-Gomara M, Cubitt D, Steele D, et al. Characterisation of rotavirus G9 strains isolated in the UK between 1995 and 1998. J Med Virol 2000; 61(4): 510-7.

[31] Palombo EA, Masendycz PJ, Bugg HC, Bogdanovic-Sakran N, Barnes GL, Bishop RF. Emergence of serotype G9 human rotaviruses in Australia. J Clin Microbiol 2000; 38(3): 1305-6.

[32] Kirkwood CD, Gentsch JR, Hoshino Y, Clark HF, Glass RI. Genetic and antigenic characterization of a serotype P[6]G9 human rotavirus strain isolated in the United States. Virology 1999; 256(1): 45-53.

[33] Unicomb LE, Podder G, Gentsch JR, et al. Evidence of highfrequency genomic reassortment of group A rotavirus strains in Bangladesh: emergence of type G9 in 1995. J Clin Microbiol 1999; 37(6): 1885-91.

[34] Ramachandran M, Das BK, Vij A, et al. Unusual diversity of human rotavirus $\mathrm{G}$ and $\mathrm{P}$ genotypes in India. J Clin Microbiol 1996; 34(2): 436-9.

[35] Ramachandran M, Kirkwood CD, Unicomb L, et al. Molecular characterization of serotype G9 rotavirus strains from a global collection. Virology 2000; 278(2): 436-44.

[36] Lin YP, Chang SY, Kao CL, et al. Molecular epidemiology of G9 rotaviruses in Taiwan between 2000 and 2002. J Clin Microbiol 2006; 44(10): 3686-94.

[37] Masendycz PJ, Palombo EA. Genetic relatedness of VP1 genes of Australian and Taiwanese rotavirus isolates. FEMS Microbiol Lett 2001; 198(2): 147-50.

[38] Palombo EA, Bugg HC, Masendycz PJ, Coulson BS, Barnes GL, Bishop RF. Multiple-gene rotavirus reassortants responsible for an outbreak of gastroenteritis in central and northern Australia. J Gen Virol 1996; 77 (Pt 6): 1223-7.
[39] Uhnoo I, Wadell G, Svensson L, Johansson ME. Importance of enteric adenoviruses 40 and 41 in acute gastroenteritis in infants and young children. J Clin Microbiol 1984; 20(3): 365-72.

[40] Kidd AH, Rosenblatt A, Besselaar TG, et al. Characterization of rotaviruses and subgroup $\mathrm{F}$ adenoviruses from acute summer gastroenteritis in South Africa. J Med Virol 1986; 18(2): 159-68.

[41] Brandt CD, Kim HW, Rodriguez WJ, et al. Adenoviruses and pediatric gastroenteritis. J Infect Dis 1985; 151(3): 437-43.

[42] Kaplan JE, Schonberger LB, Varano G, Jackman N, Bied J, Gary GW. An outbreak of acute nonbacterial gastroenteritis in a nursing home: demonstration of person-to-person transmission by temporal clustering of cases. Am J Epidemiol 1982; 116(6): 940-8.

[43] Ramirez S, Giammanco GM, De Grazia S, Colomba C, Martella V, Arista S. Genotyping of GII.4 and GIIb norovirus RT-PCR amplicons by RFLP analysis. J Virol Methods 2008; 147(2): 250-6.

[44] Kageyama T, Shinohara M, Uchida K, et al. Coexistence of multiple genotypes, including newly identified genotypes, in outbreaks of gastroenteritis due to Norovirus in Japan. J Clin Microbiol 2004; 42(7): 2988-95.

[45] Tu ET, Bull RA, Greening GE, et al. Epidemics of gastroenteritis during 2006 were associated with the spread of norovirus GII.4 variants 2006a and 2006b. Clin Infect Dis 2008; 46(3): 413-20.

[46] Thornton AC, Jennings-Conklin KS, McCormick MI. Noroviruses: agents in outbreaks of acute gastroenteritis. Disaster Manag Response 2004; 2(1): 4-9.

[47] Wu FT, Oka T, Katayama K, et al. Genetic diversity of noroviruses in Taiwan between November 2004 and March 2005. Arch Virol 2006; 151(7): 1319-27.

[48] Wu FT, Oka T, Takeda N, et al. Acute gastroenteritis caused by GI/2 sapovirus, Taiwan, 2007. Emerg Infect Dis 2008; 14(7): 1169 71 .

[49] Madeley CR, Cosgrove BP. Letter: $28 \mathrm{~nm}$ particles in faeces in infantile gastroenteritis. Lancet 1975; 2(7932): 451-2.

[50] Cook N, Myint S. Astroviruses. J Med Microbiol 1995; 42(1): 1-2.

[51] Lin HC, Kao CL, Chang LY, et al. Astrovirus gastroenteritis in children in Taipei. J Formos Med Assoc 2008; 107(4): 295-303.

[52] Melnick JL, Tagaya I, von Magnus H. Enteroviruses 69, 70, and 71. Intervirology 1974; 4(6): 369-70.

[53] Hsiung GD, Wang JR. Enterovirus infections with special reference to enterovirus 71. J Microbiol Immunol Infect 2000; 33(1): 1-8.

[54] Ho M, Chen ER, Hsu KH, et al. An epidemic of enterovirus 71 infection in Taiwan. Taiwan Enterovirus Epidemic Working Group. N Engl J Med 1999; 341(13): 929-35.

[55] Gau SS, Chang LY, Huang LM, Fan TY, Wu YY, Lin TY. Attention-deficit/hyperactivity-related symptoms among children with enterovirus 71 infection of the central nervous system. Pediatrics 2008; 122(2): e452-8.

[56] Chang LY, Lin TY, Hsu KH, et al. Clinical features and risk factors of pulmonary oedema after enterovirus-71-related hand, foot, and mouth disease. Lancet 1999; 354(9191): 1682-6.

[57] Johnsen IB, Nguyen TT, Ringdal M, et al. Toll-like receptor 3 associates with c-Src tyrosine kinase on endosomes to initiate antiviral signaling. EMBO J 2006; 25(14): 3335-46.

[58] McCartney SA, Thackray LB, Gitlin L, Gilfillan S, Virgin HW, Colonna M. MDA-5 recognition of a murine norovirus. PLoS Pathog 2008; 4(7): e1000108.

[59] Mesa MC, Rodriguez LS, Franco MA, Angel J. Interaction of rotavirus with human peripheral blood mononuclear cells: plasmacytoid dendritic cells play a role in stimulating memory rotavirus specific T cells in vitro. Virology 2007; 366(1): 174-84.

[60] Hanauer SB. Inflammatory bowel disease: epidemiology, pathogenesis, and therapeutic opportunities. Inflamm Bowel Dis 2006; 12(Suppl 1): S3-9.

[61] Wahid R, Cannon MJ, Chow M. Virus-specific CD4+ and CD8+ cytotoxic T-cell responses and long-term T-cell memory in individuals vaccinated against polio. J Virol 2005; 79(10): 5988-95.

[62] Michalak TI, Hodgson PD, Churchill ND. Posttranscriptional inhibition of class I major histocompatibility complex presentation on hepatocytes and lymphoid cells in chronic woodchuck hepatitis virus infection. J Virol 2000; 74(10): 4483-94.

[63] Guidotti LG, Chisari FV. To kill or to cure: options in host defense against viral infection. Curr Opin Immunol 1996; 8(4): 478-83.

[64] Chen KS, Wang PH, Yang SF, et al. Significant elevation of a Th2 cytokine, interleukin-10, in pelvic inflammatory disease. Clin Chem Lab Med 2008; 46(11): 1609-16. 
[65] Wood DJ, David TJ, Chrystie IL, Totterdell B. Chronic enteric virus infection in two T-cell immunodeficient children. J Med Virol 1988; 24(4): 435-44.

[66] Mosmann TR, Sad S. The expanding universe of T-cell subsets: Th1, Th2 and more. Immunol Today 1996; 17(3): 138-46.

[67] Billiau A. Interferon-gamma: biology and role in pathogenesis. Adv Immunol 1996; 62: 61-130.

[68] Seder RA, Paul WE. Acquisition of lymphokine-producing phenotype by CD4+ T cells. Annu Rev Immunol 1994; 12: 635-73.

[69] Mosmann TR, Cherwinski H, Bond MW, Giedlin MA, Coffman RL. Two types of murine helper T cell clone. I. Definition according to profiles of lymphokine activities and secreted proteins. J Immunol 1986; 136(7): 2348-57.

[70] Paludan SR. Interleukin-4 and interferon-gamma: the quintessence of a mutual antagonistic relationship. Scand J Immunol 1998; 48(5): 459-68

[71] Cavaillon JM, Fitting C, Haeffner-Cavaillon N, Kirsch SJ, Warren HS. Cytokine response by monocytes and macrophages to free and lipoprotein-bound lipopolysaccharide. Infect Immun 1990; 58(7): 2375-82.

[72] Franco MA, Greenberg HB. Role of B cells and cytotoxic T lymphocytes in clearance of and immunity to rotavirus infection in mice. J Virol 1995; 69(12): 7800-6.

[73] Guo L, Wang J, Zhou H, et al. Intranasal administration of a recombinant adenovirus expressing the norovirus capsid protein stimulates specific humoral, mucosal, and cellular immune responses in mice. Vaccine 2008; 26(4): 460-8.

[74] Weinzierl AO, Rudolf D, Maurer D, et al. Identification of HLA$\mathrm{A}^{*} 01$ - and HLA-A*02-restricted CD8+ T-cell epitopes shared among group B enteroviruses. J Gen Virol 2008; 89(Pt 9): 2090-7.

[75] Fischler B, Nystrom J, Bjornsdottir T, Lindh G, Hultgren C. Virusspecific $\mathrm{T}$ cell immune response in children and adolescents with chronic hepatitis B virus infection. J Pediatr Gastroenterol Nutr 2007; 45(1): 75-83.

[76] Freigang S, Egger D, Bienz K, Hengartner H, Zinkernagel RM. Endogenous neosynthesis $v s$ cross-presentation of viral antigens for cytotoxic T cell priming. Proc Natl Acad Sci USA 2003; 100(23): 13477-82.

[77] Buesa J, Raga JV, Colomina J, de Souza CO, Munoz C, Gil MT. Rotavirus-specific cytotoxic $\mathrm{T}$ lymphocytes recognize overlapping epitopes in the amino-terminal region of the VP7 glycoprotein. Virology 1999; 257(2): 424-37.

[78] Jaimes MC, Feng N, Greenberg HB. Characterization of homologous and heterologous rotavirus-specific T-cell responses in infant and adult mice. J Virol 2005; 79(8): 4568-79.

[79] Kobayashi S, Kobayashi M, Araki K, Shinozaki T, Yanagawa Y. Antibody prevalence against astrovirus according to age groups. Kansenshogaku Zasshi 1999; 73(6): 578-83.
[80] Schaffer FM, Newton JA. Intravenous gamma globulin administration to common variable immunodeficient women during pregnancy: case report and review of the literature. J Perinatol 1994; 14(2): 114-7.

[81] van Loon AM, Heessen FW, van der Logt JT. Antibody isotype response after human cytomegalovirus infection. J Virol Methods 1987; 15(2): 101-7.

[82] Carricart SE, Bustos D, Biganzoli P, Nates SE, Pavan JV. Isotype immune response of $\mathrm{IgG}$ antibodies at the persistence and reactivation stages of human herpes virus 6 infection. J Clin Virol 2004; 31(4): 266-9.

[83] Jenison S, Yamada T, Morris C, et al. Characterization of human antibody responses to four corners hantavirus infections among patients with hantavirus pulmonary syndrome. J Virol 1994; 68(5): 3000-6.

[84] Lundkvist A, Bjorsten S, Niklasson B. Immunoglobulin G subclass responses against the structural components of Puumala virus. $\mathrm{J}$ Clin Microbiol 1993; 31(2): 368-72.

[85] Khalife J, Guy B, Capron M, et al. Isotypic restriction of the antibody response to human immunodeficiency virus. AIDS Res Hum Retroviruses 1988; 4(1): 3-9.

[86] Tsai TH, Huang CF, Wei JC, et al. Study of IgG subclass profiles of anti-HBs in populations with different HBV infection status. Viral Immunol 2006; 19(2): 277-84.

[87] Yang YY, Huang CF, Wei JC, et al. The study of IgG subclass profiles of anti-hbc in populations with different status of $\mathrm{HBV}$ infection. Cell Mol Immunol 2005; 2(5): 393-8.

[88] Wang L, Lin SJ, Tsai JH, Tsai CH, Tsai CC, Yang CC. Antihepatitis B surface antigen IgG1 subclass is predominant in individuals who have recovered from hepatitis B virus infection, chronic carriers, and vaccinees. Med Microbiol Immunol 2005; 194(1-2): 33-8.

[89] Yang CC, Lin CC, Wang L, Ku CS, Chen CK. Anti-HBc IgG subclasses in different populations by comparing a variety of ELISA plates. J Immunoassay Immunochem 2001; 22(1): 33-45.

[90] Ahmad NM, Ahmad KM, Younus F. Severe adenovirus pneumonia (AVP) following infliximab infusion for the treatment of Crohn's disease. J Infect 2007; 54(1): e29-32.

[91] Franco MA, Greenberg HB. Immunity to rotavirus in T cell deficient mice. Virology 1997; 238(2): 169-79.

[92] Molberg O, Nilsen EM, Sollid LM, et al. CD4+ T cells with specific reactivity against astrovirus isolated from normal human small intestine. Gastroenterology 1998; 114(1): 115-22.

[93] Schaffer FM, Monteiro RC, Volanakis JE, Cooper MD. IgA deficiency. Immunodefic Rev 1991; 3(1): 15-44. 